\title{
How Companies Face Global Economic Disruption
}

Christanto, A.

University of Surabaya, Surabaya, Indonesia

\begin{abstract}
In the global economic uncertainty, the best way companies in Indonesia to survive is transforming business and human resources with information technology that refer to Good Corporate Governance. The key to survive in the market is manage operational foundation, guarantee trust from stakeholders and employee engagement that can gain positive profits.
\end{abstract}

\section{INTRODUCTION}

Global economic conditions in 2018 are uncertain and Indonesia experienced a decline compared to 2017 because exports and imports consistenly declined since 2015. Economy of Europe and China are expected to grow slowly, while United States seems to grow strongly but the inflation expectation remains high that cause volume of world trade low due to deteriorating trade relations between countries. Economic disruption expected to happen until 2020 so business people in Indonesia are required to constantly renew, innovate, and create diversification so that they can survive in the market and support the company's vision and mission, optimizing the strategies to obtain profit maximization. Many companies in Indonesia still cant survive in tight business competition, just a few large and strong companies that can survive in the global era that needs to adapt in digital technology and changes socio-political conditions.

The implementation of quality Good Corporate Governance (GCG) enables the creation of added value for stakeholders, and in turn, will create sustainable business success (Effendi 2009). GCG is a rules that manage relationship between company and stakeholders to increase company value and market valuation that establish corporate culture, existence of information disclosure, effective audit system and controlling risk. GCG need to made based on guidelines that officially issued by National Governance Policy Committee and expected to meet three dimensions, compliance, confornance and performance. Besides employee engagement, companies also need a clear and measureable framework, execution of sustainable strategies and formulating the future according the visions and missions's company. Companies that have capability can create useful values by exploiting opportunities or neutralizing threats in the company's external environment. Similarly, companies can understand the position of costs 
and identify ways that can be used to facilitate the implementation of their business-level strategies. (Hitt et al. 2001).

\section{METHODS}

This research is qualitative with interpretive paradigm that study phenomena and methods used then interpret findings, intend to analyze the reality of global economic uncertainty and the fluctuations of the Indonesian Rupiah against the US Dollar and their effect on companies in Indonesia's competitive market. This research use primary and secondary data to understand how business people deal, save and shape with economic disruption, then interpreted the findings based on Indonesian perspective. Validation is done gradually to get accurate and indepth results, starts from procurement raw data to analysis process that produce themes and disruption.

\section{RESULTS}

The result is from 2014 to 2017, population of large, medium, small industries, and investment in the manufacturing industry were increased. Now, industrial and mining sector that use high technology aggressively open recruitment for new workers that capable to use information technology such as data analysis and business intelligence, general digital or internet-based marketing, and software programming experts. Digital trends create many job opportunities, but most of them have no official legal status and Indonesia's Labor Development Index is low. So, digital trends requires a workforce transformation to learn new competencies to adapt and survive from disruption and industrial revolution 4.0. Each position in organizational structure should have a clear role in the company's strategic achievement, and companies must ready to aligning strategy that conformable with human resouce competencies, culture and organizational structure.

There is a popular adage in the community, "nothing is permanent except change". Its proven with volatility, uncertainty, complexity, and ambiguity (VUCA) that was caused of globalization, digitalization and trade war. Business and human resource transformation are important to face challenges from external and internal factors, as has been implemented by PT. BNI, Tbk. And PT. Hartono Plantation Indonesia (HPI-Argo). Digital transformation from PT. BNI, Tbk is mobile banking, digital loans, mobile remittance, chat banking and QR Codebased payment application, while HPI-Agro creates change on annual plants into seasonal plants, project development into an established organization, investment mode into operational mode, administration into strategic manager, ad-hoc into planning based, traditional 
organization into modern one, plantations into agricultural industries, offer into demand management and followers into innovators.

Process of tranformation is related to innovative ideas and must not violate business ethics and GCG principles such as transparency, accountability, responsibility, independence and fairness in aspects of strategy system, management, organization, information technology, human resources and funding. Many companies are now implementing GCG not only as regulatory obligation, but as part of company's tool and guidelines that can used as operational foundation which makes strategy and management systems works properly and correctly so trust from stakeholder raises. Implementation of sustainable GCG system encourage companies to create new values in the aspects of products, operation and services that improve company performance, and benefitly stakeholders that needed in the capital market. GCG increase stakeholer's trust and indirectly increase investment by attracting investors in their shares.

The effectiveness of an organizational structure is much influenced by the quality of leadership and the management system implemented to create a superior products and services as expected by the market. Employees sometimes feel that there is no bond with the company (Dessler 2005), that can be a problem and disappoints consumers so employee engagement is needed. Employee engagement able management to improve the conditions of employees' say, stay, and strive through efforts to build high commitment and accommodate aspects of employee satisfaction that turn to implemented into daily operational activities and ecpected to grow passion, motivation and proactive ecouragement.

\section{CONCLUSION}

The conclusion is to face global economic disruption that is full of volatility, uncertainty, complexity, and ambiguity (VUCA), company needs to create transformation and boost competitive advantage start from the leader that share positive aura and become a role model to all employees so they can move in the same direction and increase company value, market value, culture value, the openness of information, effectiveness of the audit system, risk control and profit maximization.

\section{REFERENCE}

Tayibnapis, A. Z., Wuryaningsih, L. E., Gora, R. (2019). Companies in Indonesia in the Vortex of Global Economic Disruption. Advances in Social Science, Education and Humanities Research, Vol.308. 